\title{
PEMBELAJARAN BERBASIS BUDAYA DALAM MENINGKATKAN MUTU PENDIDIKAN DI SEKOLAH
}

\author{
Oleh \\ I Ketut Tanu \\ Dosen pada Program Pascasarajana IHDN Denpasar
}

\begin{abstract}
Education means the care for the development of the students that they grow in line with their culture. In other words, any education should pay attention to the culture of the students. Today's curriculum tends to ignore this that the students are alienated from their own culture and are feeling that they are not part of the process of the education. The time the students are appreciated is the time when the education is done properly.
\end{abstract}

Key words: learning, education, culture

\section{PENDAHULUAN}

Kehidupan manusia tidak bisa terlepas dari kebudayaan, karena dalam aktivitas kehidupan sehari-hari manusia hampir selalu melibatkan dirinya dengan lingkungan sekitar, baik itu lingkungan fisik dan non fisik yang nantinya akan menciptakan suatu kebudayaan. Suatu kebudayaan terbentuk secara berangsur-angsur dalam jangka waktu yang sangat lama dan proses yang teratur. Melalui proses ini diharapkan suatu kebudayaan dari masyarakat tertentu, nantinya mampu membentuk sebuah tatanan komunitas masyarakat yang teratur, serta mampu menciptakan masyarakat yang sejahtra secara lahir bhatin.

Kebudayaan itu ada sejak manusia diciptakan. Kebiasaan yang membentuk prilaku dan kepribadian manusia diwariskan dari generasi ke generasi secara turun temurun. Budaya merupakan suatu produk dari akal budi manusia, setidaknya apabila dilakukan pendekatkan secara etemologi. Kebudayaan bisa tetap terjaga eksistensinya dan bisa diwariskan secara turun temurun, maka diperlukannya adanya perantara kebudayaan antara generasi ke generasi berikutnya. Salah satunya adalah cara yang dapat dilakukan adalah dilakukannya proses penanaman nilainilai kebudayaan dalam bidang pendidikan, baik itu pada pendidikan informal, formal, dan nonformal.

Pendidikan berbasis budaya merupakan perwujutan dari demokratisasi pendidikan melalui perluasan pelayanan pendidikan untuk kepentingan masyarakat. Pendidikan berbasis budaya menjadi sebuah gerakan penyadaran masyarakat untuk terus belajar sepanjang hayat dalam mengatasi segala tantangan kehidupan yang berubah-ubah. Konsep dan penerapannya memiliki kesamaan dengan pola pendidikan berbasis masyarakat, sebagaimana yang ditulis oleh Zubeidi (2005:132).

Pendidikan berbasis budaya (culture based education) merupakan mekanisme yang memberikan peluang bagi setiap orang untuk memperkayailmu pengetahuan dan teknologi melalui pembelajaran seumur hidup. Kemunculan paradigma pendidikan berbasis budaya lebih menekankan pada dua arus besar. Pertama, berangkat dari asumsi modernisme 
yang telah sampai pada titik kulminasinya sehingga cenderung membuat manusia untuk kembali kepada hal-hal yang bersifat natural (alami). Kedua, modernisasi sendiri yang menghendaki terciptanya demokrasi dalam segala demensi kehidupan manusia.

Berangkat dari hal tersebut, maka pendidikan harus dikelola secara lebih optimal dengan memberikan tempat seluas-luasnyabagi partisipasi masyarakat dengan muatan value cultur (kebijakan lokal) sebagai bagian dari tujuandan isi dari pendidikan. Sebagai implikasinya, pendidikan menjadi usaha kolaboratif yang melibatkan partisipasi dan peran kearifan sistem nilai budaya di dalamnya. Partisipasi dalam konteks ini berupa kerjasama antara warga dengan pemerintah dalam merencanakan, melaksanakan, menjaga dan mengembangkan aktivitas pendidikan di sekolah.

\section{PEMBAHASAN}

Berdasarkan uraian pada Pendahuluan maka berikut ini akan dipaparkan hal sebagai berikut:

\section{Pengertian Pendidikan Berbasis Budaya}

Pengertian pendidikan menurut H. Horne, "Pendidikan adalah proses yang di lakukan terus menerus dari penyesuaian yang lebih tinggi bagi makhluk manusia yang telah berkembang secara fisik dan mental, yang bebas dan sadar kepada Tuhan, seperti termanifestasi dalam alam sekitar intelektual, emosional dan kemanusiaan dari manusia”. Begitu juga menurut Ahmad D. Marimba, Beliau juga berpendapat bahwa Pendidikan adalah " bimbingan atau pimpinan secara sadar oleh pendidik terdapat perkembangan jasmani dan rohani terdidik menuju terbentuknya kepribadian yang utama".

Selanjutnya menurut UU No. 20 tahun 2003 pengertian Pendidikan adalah sebuah usaha yang di lakukan secara sadar dan terencana untuk mewujudkan suasana belajar dan proses pembelajaran agar peserta didik secara aktif mengembangkan potensi dirinya untuk memiliki kekuatan spiritual keagamaaan, membangun kepribadian, pengendalian diri, kecerdasan, akhlak mulia, serta ketrampilan yang diperlukan dirinya, masyarakat, bangsa, dan Negara. Undang - undang inilah yang menjadi dasar berdidirinya proses pendidikan yang ada di Negara Indonesia.

Budaya menurut Tyler (1871) merupakan "a complex whole which includes knowledge, belief, art, law, morals, customs, and any other capabilities and habits acquired by man as a member of society". Sementara itu, ada lagi definisi yang menyatakan bahwa budaya adalah pola utuh prilaku manusia dan produk yang dihasilkannya yang membawa pola pikir, pola lisan, pola aksi, dan artifak, dan sangat tergantung pada kemampuan seseorang untuk belajar, untuk menyampaikan pengetahunnya kepada generasi berikutnya melalui beragam alat, bahasa, dan pola nalar.

Pendidikan berbasis budaya (culture based education) merupakan mekanisme yang memberikan peluang bagi setiap orang untuk memperkaya ilmu pengetahuan dan teknologi melalui pembelajaran seumur hidup. Kemunculan paradigma pendidikan berbasis budaya lebih dipicu oleh dua arus besar. Pertama, berangkat dari asumsi modernisme yang telah sampai pada titik kulminasinya sehingga cenderung membuat manusia untuk kembali kepada hal-hal yang bersifat natural (alami). Kedua, modernisasi sendiri yang menghendaki terciptanya demokrasi dalam segala dimensi kehidupan manusia.

Berangkat dari hal tersebut, mau tidak mau pendidikan harus dikelola secara lebih optimal dengan memberikan tempat seluas-luasnya bagi partisipasi masyarakat dengan muatan value cultur (kebijakan lokal) sebagai bagian dari tujuan isi dari pendidikan. Sebagai implikasinya, pendidikan menjadi usaha kolaboratif yang melibatkan partisipasi dan peran kearifan sistem 
nilai budaya di dalamnya. Partisipasi dalam konteks ini berupa kerjasama antara warga dengan pemerintah dalam merencanakan, melaksanakan, menjaga dan mengembangkan aktivitas pendidikan. Sebagai sebuah kerja sama, maka masyarakat dengan budayanya diasumsikan mempunyai aspirasi yang harus diakomodasi dalam proses perencanaan dan pelaksanaan suatu program pendidikan yang berpondasi dari akar sistem nilai budayanya sendiri. Lebih jauh, era desentralisasi-otonomi juga berdampak pada semakin terbukanya kebebasan yang dimiliki masyarakat untuk merancang dan melaksanakan pendidikan sesuai kebutuhan sendiri. Akibatnya, upayaupaya menyelenggarakan pendidikan berbasis culture bassed education dewasa ini semakin marak.

Dalam pandangan tradisional, pendidikan dipandang sebagai kegiatan yang bertujuan atau sebagai jalan menuju pencapaian tujuan yang berada di luar proses pendidikan itu sendiri. Misalnya pandangan Aristoteles yang melihat pendidikan sebagai sarana untuk membantu dalam pencapaian kebahagiaan, kehidupan yang lebih baik, dan keadaan yang final. Artinya, di sini dipahami bahwa pendidikan adalah alat untuk mencapai tujuan, dengan pengandaian bahwa prosesnya terpisah. Lain lagi halnya menurut Leo Toltoy, pendidikan tidak mempunyai sasaran utama di luar pendidikan itu sendiri. Justru tujuan yang ingin dicapai dalam pendidikan adalah berasal dari prosesnya sendiri, yaitu proses bagaimana "memahami" realitas yang ada. Dengan demikian, pendidikan sangat terkait sekali dengan kebudayaan. Artinya, konsep ini merangkum seluruh nilai dalam budaya masyarakat yang masih eksis.

Dari paparan tersebut dapat dilihat tidak disangsikan lagi bahwa kaitan antara pendidikan dan kebudayaan adalah sangat mutlak. Pendidikan adalah "proses" (kebudayaan) manusia untuk mengembangkan kualitas dirinya menuju arah yang lebih baik.
Pendidikan berbasis budaya merupakan perwujudan dari demokratisasi pendidikan melalui perluasan pelayanan pendidikan untuk kepentingan masyarakat. Pendidikan berbasis budaya menjadi sebuah gerakan penyadaran masyarakat untuk terus belajar sepanjang hayat dalam mengatasi segala tantangan kehidupan yang berubah-ubah dan semakin berat. Secara konseptual, pendidikan berbasis budaya adalah model penyelenggaraan pendidikan yang bertumpu pada prinsip "dari konsep budaya, digerakkan oleh budaya dan untuk menciptakan budaya baru yang bercorak dan bernilai lebih dari budaya sebelumnya".

Pendidikan dengan konsep budaya artinya pendidikan memberikan jawaban dan solusi atas penciptaan budaya yang didasari oleh kebutuhan masyarakat, tentu dengan tata nilai dan sistem yang berlaku di dalamnya. Pendidikan berbudaya artinya masyarakat sebagai pemilik budaya dengan segala tatanan nilai dan sistemnya ditempatkan sebagai subjek/ pelaku pendidikan, bukan objek pendidikan. Pada konteks ini, semua unsur yang melingkupi masyarakat dapat berperan aktif dalam terciptanya sebuah budaya yang melingkupi masyarakat itu sendiri. Indonesia sebagai negara yang cukup potensial dalam perkembangan pendidikan tentu saja harus bisa menyesuaikan dengan kondisi kekinian. Keniscayaan akan format pendidikan yang lebih banyak sudah menjadi "kewajiban" kita bersama dalam usaha merealisasikannya.

Melakukan suatu usaha pembebasan terhadap pendidikan yang selama ini banyak diwarnai nilai-nilai yang meng-hegemoni kreativitas berpikir anak didik, telah mengharuskan kita berusaha merubah sembari berusaha memberikan konsep baru tentang pendidikan yang sebenarnya. Memberikan peluang sepenuhnya kepada anak didik dalam rangka mengembangkan kemampuan sesuai dengan talentanya. Hal tersebut akan berimplikasi positif terhadap pertumbuhan dan perkembangannya secara alamiah (nature). 
2. Konteks Pendidikan Berbasis Budaya

Pendidikan merupakan topik yang tidak pernah usai dibicarakan dan didiskusikan. Diskusi itu pun seolah tidak berujung karena selalu tidak pernah menemukan titik temu berupa solusi konkrit untuk mengatasi permasalahan pendidikan di indonesia, bahkan selalu muncul masalah baru. Namun berbagai pihak, masih terus semangat memikirkan jalan terbaik bagi sistem pendidikan di Indonesia. Hal ini memang wajar mengingat pendidikan merupakan hal pokok dalam pengembangan sumber daya manusia (SDM) dan pendidikan sangat mempengaruhi tingkat peradaban suatu bangsa.

Ketika pendidikan gagal, maka suatu negara akan sulit untuk berkembang. Misalnya saat ini di Indonesia timbul berbagai masalah bangsa yang silih berganti, maka dapat dikatakan kegagalan pendidikan juga berperan dalam terjadinya masalah ini. Ketika korupsi marak terjadi menguras kekayaan bangsa ini, maka dapat dikatakan bahwa kegagalan pendidikan untuk membentuk SDM yang berkarakter dan bermoral sebagai penyebab akan hal itu. Ketika reformasi yang telah digulirkan sekian tahun belum mampu membuahkan hasil maksimal, maka dapat dikatakan kegagalan pendidikan menciptakan masyarakat cerdas sebagai penyebab akan hal itu. Bahkan ketika saat ini kita masih berdiskusi tentang pendidikan, dapat dikatakan bahwa hal itu sebagai dampak ketika selama ini pendidikan belum mampu meciptakan SDM yang cerdas yang dapat merumuskan sistem pendidikan yang ideal untuk indonesia.

Melihat beberapa fakta di atas dan memandang out put pendidikan saat ini, dapat disimpulkan bahwa harus ada reformasi pendidikan di indonesia. Reformasi sangat penting sebelum paradigma yang salah semakin menguasai sistem pendidikan di indonesia. Konstitusi mengamanatkan bahwa salah satu tujuan bangsa adalah mencerdaskan kehidupan bangsa. Oleh karena itu pendidikan harus diarahkan untuk mampu mencerdaskan kehidupan bangsa sebagai perwujudan dari cita-cita negara itu. Secara demografis, besarnya jumlah penduduk di Indonesia seharusnya sebagai aset yang menjadi kelebihan dibanding negara lain. Seandainya penduduk dengan jumlah yang besar itu merupakan SDM yang unggul dan berbudaya, maka kemajuan pun akan menjadi milik bangsa ini.

a. Integrasi Pendidikan dan Kebudayaan

Kebudayaan adalah unsur fundamental dalam pengembangan pendidikan secara utuh. Pendidikan yang baik tidak serta merta hanya mengembangkan intelektualitas tetapi yang terpenting intelektualitas yang berbudaya. Sejak didirikannya negara ini, para founding fathers telah memperhitungkan bahwa pendidikan merupakan salah satu sarana untuk melihat ragam budaya nasional, sehingga merevitalisasi pendidikan harus memasukkan unsur-unsur nilai budaya yang menjadi penopang kualitas pendidikan. Di Negeri Jepang, sistem pendidikannya diramu sedemikian baik dengan pengintegrasian sistem pendidikan dengan nilai-nilai budaya lokal setempat, tanpa harus memperhitungkan sistem pendidikan global, namun kendati demikian ternyata standar pendidikan Jepang mampu bersaing dengan kualitas pendidikan global. Hal ini terjadi karena fokus pengembangan pendidikan di Negeri Sakura tersebut dilandasi dengan pengembangan kebudayaan lokal setempat yang secara otomatis sistem pendidikan tersebut menjadi ukuran standar pendidikan global.

Berbeda di Indonesia, eksperimen terhadap pendidikan yang ada selama ini dibajak dari standar global yang senyata telah membabibutakan penerapan pendidikan yang meninggalkan nilai-nilai keaslian budaya lokal. Keaslian pendididikan yang berbudaya termarjilkan akibat harus mengikuti standarstandar global. Kehadiran sistem baru dalam pendidikan yang terbangun lebih banyak 
memberikan efek samping yang kurang baik dibandingkan dari manfaatnya, sehingga masalah kompleksitas peningkatan kualitas pendidikan saat ini adalah masalah yang hanya berorientasi pada pengejaran standar global, sehingga kecenderungan pendidikan terstigma oleh pengejaran angka semata. Para ahli antropologi seperti Theodore Brameld melihat keterkaitan yang sangat erat antara pendidikan, masyarakat, dan kebudayaan. Antara pendidikan dan kebudayaan terdapat hubungan yang sangat erat dalam arti keduanya berkenan dengan suatu hal yang sama yaitu nilai-nilai.

Manusia, masyarakat, budaya, sebagai tiga dimensi dari hal yang bersamaan. Oleh sebab itu, pendidikan tidak dapat terlepas dari kebudayaan dan hanya dapat terlaksana dalam suatu masyarakat. Apabila kebudayaan mempunyai tiga unsur penting yaitu kebudayaan sebagai suatu tata kehidupan (order), kebudayaan sebagai suatu proses, dan kebudayaan yang mempunyai suatu visi tertentu (goals), maka pendidikan dalam rumusan tersebut adalah sebenarnya proses pembudayaan. Dengan demikian tidak ada proses suatu pendidikan tanpa kebudayaan dan tanpa masyarakat, dan sebaliknya tidak ada suatu kebudayaan dalam pengertian suatu proses tanpa pendidikan, dan proses kebudayaan dan pendidikan hanya dapat terjadi dalam hubungan antar manusia di dalam suatu masyarakat tertentu. Betapa suatu kebudayaan tanpa adanya proses pendidikan berarti kemungkinan kebudayaan tersebut punah. Pendidikan yang terlepas dari kebudayaan akan menyebabkan alienasi dari subjek yang dididik.

\section{b. Kebudayaan Untuk Pendidikan}

Kebudayaan yang menjadi roh pendidikan adalah kebudayaan dalam tataran nilai. Kebudayaan tersebut bukanlah kebudayaan yang statis, namun responsif-evaluatif dengan unsur yang terkandung di dalamnya. Koentjaraningrat merumuskan tujuh unsur kebudayaan: sistem religi dan upacara keagamaan, sistem dan organisasi kemasyarakatan, sistem pengetahuan, bahasa, kesenian, sistem mata pencaharian hidup, dan sistem teknologi dan peralatan. Dengan demikian memisahkan pendidikan dari kebudayaan merupakan suatu kebijakan yang merusak perkembangan kebudayaan sendiri, malahan mengkhianati keberadaan proses pendidikan sebagai proses pembudayaan.

Nilai-nilai budaya yang menjadi roh pendidikan merupakan nilai luhur yang telah hidup di msyarakat. Di sana terdapat pesan hidup, pesan moral sehingga tercipta masyarakat yang berkarakter. Unsur universal dan nilai budaya terdapat dalam bahasa, teknologi, organisasi sosial, sistem pengetahuan dan kesenian. Di bidang teknologi misalnya, kita dapat melihat peninggalan-peninggalan sejarah dan arsitektur tradisional seperti berbagai rumah adat. Organisasi sosial dapat kita lihat di dalam organisasi yang masih hidup seperti sistem subak di Bali.

Apabila kebudayaan menjadi roh pendidikan, maka pendidikan pun akan mampu menjawab permasalahan dalam masyarakat karena yang dipelajari bersumber dari masyarakat itu sendiri. Misalnya saat ini untuk menentukan cara becocok tanam yang baik di Indonesia kita malah mengadopsi teori pertanian dari Jepang yang belum tentu sesuai dengan keadaan di indonesia. Ketika pendidikan diintegrasikan dengan kebudayaan maka terdapat manfaat timbal balik. Misalnya pendidikan mengajarkan nilai-nilai budaya dalam seni budaya seperti tarian, dongeng dan lain sebagainya maka secara otomatis tindakan tersebut juga sebagai salah satu bentuk pelestarian budaya.

\section{Implementasi Pendidikan Berbasis Budaya.}

Konsep pendidikan berbasis budaya adalah pendidikan yang diselenggarakan untuk memenuhi standar nasional pendidikan yang 
diperkaya dengan keunggulan komparatif dan kompetitif berdasar nilai-nilai luhur budaya agar peserta didik secara aktif dapat mengembangkan potensi diri sehingga menjadi manusia yang unggul, cerdas, visioner, peka terhadap lingkungan dan keberagaman budaya, serta tanggap terhadap perkembangan dunia. Standar mutu pendidikan berbasis budaya mencakup: standar isi; standar proses; standar kompetensi lulusan; standar pendidik dan tenaga kependidikan; standar sarana dan prasarana; standar pengelolaan; standar pembiayaan; dan standar penilaian pendidikan (PP No. 19/2005).

a. Standar isi: memuat kerangka dasar dan struktur kurikulum pendidikan berbasis budaya yang mengintegrasikan muatan nilai luhur budaya dengan ilmu pengetahuan, pendidikan, teknologi, humaniora, kesenian, olahraga dan kegiatan sosial.

b. Standar proses: mengedepankan partisipasi aktif peserta didik dengan memperhatikan keunikan pribadi, nilai kebebasan berkreasi, kesopanan, ketertiban, kebahagiaan, kebersamaan, keadilan, dan saling menghormati.

c. SKL: Standar kompetensi lulusan mencakup sikap, pengetahuan, dan keterampilan. Ketentuan lebih lanjut mengenai sikap, pengetahuan, dan keterampilan diatur dengan Peraturan Gubernur. d. Standar pendidik dan tenaga kependidikan: memenuhi prinsip profesionalitas dan memahami nilai luhur budaya; wajib mengembangkan pemahaman dan menerapkan nilai luhur budaya. Pendidik dan tenaga kependidikan yang tidak melaksanakan kewajiban mengembangkan pemahaman dan menerapkan nilai luhur budaya dikenai sanksi administratif.

e. Standar sarpras: meliputi SNP sebagai standar pelayanan minimal ditambah dengan sarana dan prasarana untuk mendukung terlaksananya pendidikan berbasis budaya. Penyediaan sarpras merupakan tanggung jawab Pemda untuk mendukung terlaksananya pendidikan berbasis budaya pada: rintisan sekolah bertaraf internasional; sekolah bertaraf internasional; dan pendidikan khusus. Pemda membantu penyediaan sarana dan prasarana untuk mendukung terlaksananya pendidikan berbasis budaya. Pemda melaksanakan pengawasan terhadap bantuan sarana dan prasarana.

f. Standar Pengelolaan Pendidikan: Standar pengelolaan pendidikan digunakan untuk kerangka dasar tata kelola pendidikan di jalur formal, nonformal dan informal berbasis budaya. Pengelolaan satuan pendidikan jalur formal dilakukan melalui jenjang pendidikan dasar dan menengah dengan menerapkan manajemen berbasis sekolah. Pengelolaan satuan pendidikan jalur nonformal dilakukan dengan menerapkan manajemen berbasis masyarakat. Pengelolaan pendidikan informal dikelola secara mandiri oleh keluarga dan/atau lingkungan masyarakat.

g. Standar Pembiayaan: Standar pembiayaan terdiri atas biaya investasi, biaya operasional dan biaya personal.

1. Pemda bertanggung jawab terhadap pembiayaan untuk mendukung terlaksananya pendidikan layanan khusus sesuai dengan kewenangannya. Pemda membantu pembiayaan untuk mendukung terlaksananya pendidikan berbasis budaya pada satuan pendidikan di jalur formal, nonformal, dan informal yang diselenggarakan masyarakat.

2. Pemda melaksanakan pengawasan terhadap bantuan pembiayaan.

h. Standar Penilaian: Penilaian pendidikan meliputi: mekanisme; prosedur; dan instrumen penilaian hasil belajar peserta didik. Penilaian dilaksanakan dengan pendekatan evaluasi berkesinambungan 
dan evaluasi otentik dengan menggunakan berbagai metode. Evaluasi berkesinambungan adalah evaluasi hasil belajar yang diikuti dengan tindak lanjutnya, data hasil evaluasi belajar dimanfaatkan sebagai bahan untuk menyempurnakan program pembelajaran, memperbaiki kelemahankelemahan pembelajaran, dan kegiatan bimbingan belajar pada peserta didik yang memerlukannya.

Evaluasi otentik adalah evaluasi yang berbasis kompetensi, peserta didik bisa dikatakan belajar dengan benar dan baik bila sudah bisa mengimplementasikan hasil belajar dan mengaplikasikan keterampilannya dalam kehidupan sehari-hari. Fokus pelaksanaan evaluasi otentik antara lain: mengevaluasi kemampuan peserta didik untuk menganalisis materi pembelajaran dan kejadian di sekitarnya, mengevaluasi kemampuan peserta didik untuk mengintegrasikan apa yang telah dipelajari, kreativitas, kemampuan kerja sama, dan kemampuan mengekspresikan secara lisan dan praktik.

\section{Pembelajaran Berbasis Budaya}

Pembelajaran adalah suatu kombinasi yang tersusun, meliputi unsure-unsur manusiawi, material, fasilitas, perlengkapan, dan prosedur yang salinng mempengaruhi untuk mencapai tujuan pembelajaran (Aqib, 2002:41). Pembelajaran berbasis budaya merupakan strategi penciptaan lingkungan belajar dan perancangan pengalaman belajar yang mengintegrasikan budaya sebagai bagian dari proses pembelajaran. Dalam pembelajaran berbasis budaya, budaya menjadi sebuah metode bagi siswa untuk mentrasformasikan hasil observasi mereka ke dalam bentuk-bentuk dan prinsip-prinsip yang kreatif tentang alam sehingga peran siswa bukan sekedar meniru atau menerima saja informasi, tetapi berperan sebagai penciptaan makna, pemahaman dan arti dari informasi yang diperolehnya.
Pembelajaran Berbasis Budaya (PBB) merupakan strategi penciptaan lingkungan belajar dan perancangan pengalaman belajar yangmengintegrasikan seni dan budaya sebagai bagian dari proses pembelajaran, dan mengakui seni dan budaya sebagai bagian yang fundamental bagi pendidikan, ekspresi dan komunikasi suatu gagasan, serta perkembangan pengetahuan (Pannen, 2002). PBB merupakan salah satu cara yang dipersepsikan agar dapat : menjadikan pembelajaran bermakna dan kontekstual - sangat terkait dengan komunitas budaya di manasuatu bidang ilmu dipelajari dan akan diterapkan nantinya, dan dengan komunitas budaya dari mana siswa berasal, serta menjadikan pembelajaran menarik dan menyenangkan. Goldberg (2000) Mengemukakan pembelajaran berbasis budaya meliputi 3 macam, yaitu:

1. Siswa belajar tentang Budaya (Menempatkan Budaya sebagai Bidang Ilmu)

Proses belajar tentang budaya, sudah cukup dikenal selama ini, misalnya mata pelajaran kesenian dan kerajinan tangan, seni dan sastra, seni suara, melukis atau menggambar, seni musik, seni drama, tari dan lain-lain. Budaya dipelajari dalam satu mata pelajaran khusus, tentang budaya. Mata pelajaran tersebut tidak terintegrasi dengan mata pelajaran lain, dan tidak berhubungan satu sama lain.

2. Siswa belajar dengan Budaya

Belajar dengan budaya maka budaya dan perwujudannya media pembelajaran dalam proses belajar, menjadi konteks dan contoh-contoh tentang konsep atau prinsip dalam suatu mata pelajaran, menjadi konteks penerapan prinsip atau prosedur dalam suatu mata pelajaran. Menurut Goldberg (2001), pembelajaran yang memanfaatkan seni dan budaya memungkinkan siswa dan tenaga pengajar menyadari bahwa seni dan 
budaya merupakan ekspresi ide dan gagasan yang aestetik dalam suatu konteks komunitas budaya. Hal ini mendukung tercapainya pemahaman siswa yang lebihkontekstual dan bermakna terhadap bidang ilmu yang dipelajari, sekaligus pengenalan dan apresiasi seni dan budaya dalam komunitas budayanya.

3. Siswa belajar melalui Budaya

Belajar melalui budaya merupakan metode yang memberikan kesempatan kepada siswa untuk menunjukkan pencapaian pemahaman atau makna yang diciptakannya dalam suatu mata pelajaran melalui ragam perwujudan budaya. Belajar melalui budaya merupakan salah satu bentuk multiple representation of learning assessment atau bentuk penilaian pemahaman dalam beragam bentuk.

\section{Komponen Pembelajaran Berbasis Budaya}

Pembelajaran berbasis budaya merupakan strategi pembelajaran yang berbeda dari strategi pembelajaran yang berbasiskan bidang studi yang biasa digunakan oleh para guru di banyak sekolah. Pembelajaran berbasis budaya lebihmenekankan tercapainya pemahaman yang terpadu (integrated understanding) dari pada sekedar pemaha-man mendalam (inert understanding) (Krajcik, Czemiak, Berger, 1999). Adapun komponen-komponen pembelajaran berbasis budaya, antara lain :

1. Substansi (Materi) dan Kompetensi Bidang Ilmu

Pemahaman terpadu sebagai hasil pembelajaran berbasis budaya mempersyaratkan adanya penciptaan makna oleh siswa atas substansi bidang ilmu dan konteksnya. Konteks dalam hal ini adalah komunitas budaya. Substansi meliputi:

a. Content knowledge, yaitu konsep dan prinsip dalam bidang ilmu. b. Inquiry and promlem solving knowledge, yaitu pengetahuan tentang proses penemuan dan proses penyelesaian masalah dalam bidang ilmu.

c. Epistemic knowledge, yaitu pengetahuan tentang aturan main yang berlaku dalam bidang ilmu.

2. Kebermaknaan dan Proses Pembelajaran, yang meliputi :

a. Tugas yang bermakna bersifat kontekstual karena dirancang dari pengetahuan dan pengalaman awal siswa berdasarkan contoh-contoh dan penerapan aktivitas sehari-hari pada konteks komunitas budayanya.

b. Interaksi aktif, yang merupakan sarana terjadinya proses negoisasi dalam penciptaan arti atau interaksi harus bermakna bagi siswa dan memfasilitasi terjadinya proses penciptaan makna. Terdapat beragam metode yang dapat dirancang dalam pembelajaran berbasis budaya, antara lain pembelajaran melalui proyek dan pembelajaran berbasis masalah.

c. Penjelasan dan penerapan bidang ilmu secara kontekstual. Dalam penjelasan dan penerapan bidang ilmu secara kontekstual guru maupun siswa bertumpu pada pengalaman dan pengetahuan awal siswa dalam konteks komunitas budaya sebagai titik awal proses belajar.

3. Penilaian Hasil Belajar

Beragam teknik dan alat ukur hasil belajar digunakan dalam pembelajaran berbasis budaya yang pada dasarnya memiliki kelebihan dan kekurangan. Dalam upaya siswa untuk menunjukkan keberhasilan dalam belajar dengan penciptaan makna dan pemahaman terpadu, siswa dapat menggunakan beragam perwujudan, misalnya poster, puisi, catatan harian, laporan, tarian, lukisan, dan ukiran. 
4. Peran Budaya

Budaya dalam berbagai perwujudannya secara instrumental dapat berfungsi sebagai media pembelajaran dalam proses belajar. Dalam pembelajaran berbasis budaya, peran budaya dalam memberikan suasana baru yang menarik untuk mempelajari suatu bidang ilmu yang dipadukan secara interaksi aktif dalam proses pembelajaran. Pemanfaatan berbagai sumber belajar Dalam pembelajaran berbasis budaya, pemanfaatan berbagai sumber belajar mencakup pemanfaatan bahasa sebagai alat komunikasi ide dan pemanfaatan komunikasi budaya sebagai konteks proses pembelajaran.

\section{SIMPULAN}

\subsection{Simpulan}

1. Pendidikan Berbasis Budaya dalam pembelajaran sangat bermanfaat bagi pemaknaan awal proses dan hasil belajar, karena peserta didik mendapatkan pengalaman belajar yang kontekstual dan bahan apersepsi untuk memahami konsep ilmu pengetahuan dalam budaya lokal yang dimiliki.

2. Belajar tentang budaya, melalui budaya, dan dengan budaya merupakan metode yang memberikan kesempatan kepada siswa untuk menunjukkan pencapaian pemahaman atau makna yang diciptakannya dalam suatu mata pelajaran melalui ragam perwujudan budaya.

3. Model pengintegrasian budaya dalam pembelajaran dapat memperkaya budaya lokal tersebut, yang pada gilirannya juga dapat mengembangkan dan mengukuhkan budaya nasional yang merupakan puncakpuncak budaya lokal dan budaya etnis yang berkembang.

4. Pembelajaran Berbasis Budaya merupakan strategi penciptaan lingkungan belajar dan perancangan pengalaman belajar yangmengintegrasikan seni dan budaya sebagai bagian dari proses pembelajaran, dan mengakui seni dan budaya sebagai bagian yang fundamental bagi pendidikan, ekspresi dan komunikasi suatu gagasan, serta perkembangan pengetahuan (Pannen, 2002). PBB merupakan salah satu cara yang dipersepsikan agar dapat :menjadikan pembelajaran bermakna dan kontekstual - sangat terkait dengan komunitas budaya di manasuatu bidang ilmu dipelajari dan akan diterapkan nantinya, dan dengan komunitas budaya dari mana siswa berasal, serta menjadikan pembelajaran menarik dan menyenangkan.

5. Pembelajaran berbasis budaya merupakan strategi pembelajaran yang berbeda dari strategi pembelajaran yang berbasiskan bidang studi yang biasa digunakan oleh para guru di banyak sekolah. Pembelajaran berbasis budaya lebih menekankan tercapainya pemahaman yang terpadu (integrated understanding) dari pada sekedar pemaha-man mendalam (inert understanding) (Krajcik, Czemiak, Berger, 1999).

\subsection{Saran}

1. Sebagai seorang calon guru, hendaklah mulai melirik budaya sebagai salah satu sarana dalam proses pendidikan, karena pada dasarnya pendidikan dengan konsep budaya berarti pendidikan tersebut memberikan jawaban dan solusi atas penciptaan budaya yang didasari oleh kebutuhan masyarakat, tentu dengan tata nilai dan sistem yang berlaku di dalamnya.

2. Mengingat Indonesia sebagai negara yang cukup potensial dalam perkembangan pendidikan tentu saja harus bisa menyesuaikan dengan kondisi kekinian. Keniscayaan akan format pendidikan yang lebih banyak sudah menjadi "kewajiban" 
kita bersama dalam usaha merealisasikannya.

3. Melakukan suatu usaha pembebasan terhadap pendidikan yang selama ini banyak diwarnai nilai-nilai yang menghegemoni kreativitas berpikir anak didik, telah mengharuskan kita berusaha merubah sembari berusaha memberikan konsep baru tentang pendidikan yang sebenarnya. Memberikan peluang sepenuhnya kepada anak didik dalam rangka mengembangkan kemampuan sesuai dengan talentanya. Hal tersebut akan berimplikasi positif terhadap pertumbuhan dan perkembangannya secara alamiah (nature). Itulah salah satu harapan, dengan adanya pendidikan berbasis budaya.

\section{DAFTAR PUSTAKA}

Abu Ahmadi dan Widodo Supriyono. 1991. Psikologi belajar. Jakarta : Rineka Cipta.

Ad. Rooijakkers. 1990. Mengajar Dengan Sukses. Jakarta : Gramedia.

Aqib, Zainal.2002. Profesionalisme Guru

Dalam pembelajaran. Surabaya: Insan Cendikia.

Buletin BNSP. Standar Pendidik Dan Tenaga Kependidikan, edisi 3, 2006

Danim, Sudarman dan Khairi. 2011. Profesi Kependidikan. Bandung : CV. Alfabeta.

Djamarah, Saiful Bahri.1996. Strategi Belajar Mengajar. Jakarta : Rineka Cipta.
Imam Machali dan Ara Hidayat. 2012. Pengelolaan Pendidikan : Konsep, Prinsip dan Aplikasi dalam mengelola sekolah dan Madrasah. Yogyakarta : Kaukaba.

J. J. Hasibuan dan Moerdijono. 1988. Proses Belajar Mengajar. Jakarta: Rajawali Press.

Michael W. Galbrait, Community Based Aducation Organizations ang The Delivery of the Lifelong Learning Opportunities, dalam Zubeidi. 2005. Pendidikan Berbasis Masyarakat Upaya Menawarkan Solusi Terhadap Berbagai Problem Sosial. Yogyakarata: Pustaka Pelajar.

Pannen, P. 2002. Contextual Constructivism: Creative Teaching through Indigenous Arts. Asia FellowResearch Report. Bangkok: Asian Scholarship Foundation.

Pidarta, Made. t.th. Pengelolaan Kelas. Surabaya: Usaha Nasiaonal.

Soemanto, Wasty. 1982. Dasar dan Teori Pendidikan Dunia. Surabaya : Usaha Pendidikan Nasional.

Tanu, I Ketut. 2013. Bahan Ajar Sosiologi Pendidikan. Denpasar : Sari Khayangan.

Undang - Undang Sisdiknas No. 20 tahun 2003

Winata, Putra. 1997. Strategi Belajar Mengajar. Jakarta : Depdikbud. 